\title{
The DOE Bioenergy Research Centers: History, Operations, and Scientific Output
}

\author{
Steven C. Slater ${ }^{1,2,3} \cdot$ Blake A. Simmons $^{4}$ - Tamara S. Rogers ${ }^{5} \cdot$ Margaret F. Phillips $^{1,3}$ • \\ Kristy Nordahl ${ }^{4} \cdot$ Brian H. Davison ${ }^{5}$
}

Published online: 20 August 2015

(C) The Author(s) 2015. This article is published with open access at Springerlink.com

\begin{abstract}
Over the past 7 years, the US Department of Energy's Office of Biological and Environmental Research has funded three Bioenergy Research Centers (BRCs). These centers have developed complementary and collaborative research portfolios that address the key technical and economic challenges in biofuel production from lignocellulosic biomass. All three centers have established a close, productive relationship with DOE's Joint Genome Institute (JGI). This special issue of Bioenergy Research samples the breadth of basic science and engineering work required to underpin a diverse, sustainable, and robust biofuel industry. In this report, which was collaboratively produced by all three BRCs, we discuss the BRC contributions over their first 7 years to the development of renewable transportation fuels. We also highlight the BRC research published in the current issue and discuss technical challenges in light of recent progress.
\end{abstract}

Electronic supplementary material The online version of this article (doi:10.1007/s12155-015-9660-8) contains supplementary material, which is available to authorized users.

Steven C. Slater

scslater@winnowgen.com

1 Great Lakes Bioenergy Research Center, University of Wisconsin-Madison, Madison, WI 53706, USA

2 Present address: WinnowGen, Inc, Madison, WI 53717, USA

3 Present address: Midwestern BioAg, Madison, WI 53717, USA

4 Joint BioEnergy Institute, Lawrence Berkeley National Laboratory, Emeryville, CA 94608, USA

5 BioEnergy Science Center, Oak Ridge National Laboratory, Oak Ridge, TN 37831, USA
Keywords Bioenergy · Biomass · US Department of Energy · Great Lakes Bioenergy Research Center · Bioenergy Science Center $\cdot$ Joint Bioenergy Institute $\cdot$ Collaborative Research Center

$\begin{array}{ll}\text { Abbreviations } \\ \text { BRC } & \text { Bioenergy Research Center } \\ \text { BESC } & \text { BioEnergy Science Center } \\ \text { GLBRC } & \text { Great Lakes Bioenergy Research Center } \\ \text { JBEI } & \text { Joint BioEnergy Research Institute } \\ \text { JGI } & \text { Joint Genome Institute } \\ \text { DOE } & \text { US Department of Energy } \\ \text { BER } & \text { Office of Biological and Environmental Research, } \\ & \text { DOE } \\ \text { CBP } & \text { Consolidated bioprocessing }\end{array}$

\section{Introduction}

In late 2007, the US Department of Energy (DOE), through the Office of Biological and Environmental Research (BER), funded three Bioenergy Research Centers (BRCs): (1) the Joint BioEnergy Institute (JBEI), led by Lawrence Berkeley Laboratory, (2) the Great Lakes Bioenergy Research Center (GLBRC), led by the University of Wisconsin-Madison in close partnership with Michigan State University, and (3) the Bioenergy Science Center (BESC), led by Oak Ridge National Laboratory. Their mission, broadly stated, is to develop the scientific and engineering approaches, together with supporting technologies, which will underpin conversion of lignocellulosic biomass into liquid transportation fuels.

Founding of the BRCs was the culmination of several years of intensive assessment of the potential for lignocellulosic biofuels. In 2005, the DOE and the US Department of 
Agriculture (USDA) co-published a document that is commonly referenced as the "Billion Ton Study" [1] (updated in 2011 [2]). The purpose of the study was "to determine whether the land resources of the USA are capable of producing a sustainable supply of biomass sufficient to replace $30 \%$ or more of the country's present petroleum consumption," an amount of biomass equivalent to about one billion tons per year. The study concluded that nearly 1.3 billion tons could be potentially available, primarily as crop and forestry residues, and that additional resources could be made available through production of dedicated biomass crops. This was later updated to project a growth in available biomass from around 500 million dry tons in 2012 to 900 million dry tons in 2022 (baseline case). On a theoretical feedstock basis, it is noted that oil at \$23/barrel and cellulosic biomass at $\$ 60 /$ dry ton has the same cost per unit energy ( $\$ 4 /$ GJ) [3]. A workshop in June 2005 generated an outline for a research program to address roadblocks in the development of a biomass-based biofuel industry [4]. In combination with other reports describing visions for biofuels and biobased products [5-8], these documents laid a path toward energy and chemical industries based on lignocellulosic materials.

The DOE developed an initiative for conversion of this renewable biomass resource to fuels and proposed support of several Bioenergy Research Centers focused on biological routes for the production of liquid fuels from lignocellulosic biomass. Specifically, BER sought to establish "multidisciplinary research and technology development centers that will conduct comprehensive, integrated research and training programs in energy-related systems and synthetic biology. The centers will involve diverse disciplines that included genomics, microbial and plant biology, genetics, proteomics, physiology, biochemistry, structural and computational biology, bioinformatics, and engineering" [9]. Cellulosic ethanol was the exemplar fuel, in part, because (1) ethanol is already integrated in the fuel supply, (2) switching from starch-based to cellulose-based sugars for ethanol fermentation could have significant positive environmental consequences, and (3) much of the technology required to make cellulosic sugars for ethanol production is also applicable to production of other fuels from these sugars. BER explicitly recognized the integrative nature of the science and engineering necessary to attack the many complex issues facing biomass conversion to fuels and chose to fund centers, rather than individual grants, to support this integration. This center-based approach for multidisciplinary fundamental bioenergy research was both a new approach for bioenergy and a change for DOE [10]. By late FY2007, BER had completed the review process and established the three BRCs.

Bioenergy Science Center Biomass recalcitrance - or the resistance of plants to deconstruction - is the primary barrier to efficient and economical accession of fermentable sugars for second-generation biofuels that will directly displace petroleum [11]. Understanding and overcoming this recalcitrance continues to be the central research theme of BESC. The defining goal of BESC is "to enable the emergence of a sustainable cellulosic biofuel industry by leading advances in science and science-based innovation resulting in the removal of recalcitrance as an economic barrier." Convinced that biotechnological approaches hold the most promise for achieving these breakthroughs, BESC is developing plants that are easier to deconstruct and microbes that more effectively convert lignocellulose into simple sugars. BESC - while led by Oak Ridge National Laboratory (ORNL) - is the most virtual of the BRCs and sought researchers from institutions across the USA to bring breadth and depth of expertise to the challenge of overcoming biomass recalcitrance. BESC currently has 18 partners from national laboratories, academia, industry, and a private foundation. BESC has changed its composition by adding and discontinuing about five partners over the years.

BESC's targeted focus on recalcitrance is singular among comparable institutions worldwide. In the past 7 years, BESC has made crucial progress toward understanding, manipulating, and managing plant cell wall recalcitrance and conversion. Notably, the BESC team proved the core concept that multiple genes control cell wall recalcitrance and that manipulating these genes can yield perennial biofeedstocks with enhanced deconstruction. This research paves the way for improving feedstocks directly or by genetic modification. In conversion science, BESC has identified and validated key microbial gene and enzyme targets for consolidated bioprocessing (CBP), a game-changing, one-step strategy that uses a single microbe or culture to both deconstruct biomass and ferment resulting sugars into fuels. Researchers are beginning to modify these CBP targets to improve conversion and enhance products. In addition, BESC has shown the potential of thermophilic microbes in biomass conversion and identified the critical deconstruction enzymes for key components of lignocellulosic biomass.

Great Lakes Bioenergy Research Center GLBRC's mission is to "perform the basic research that generates technology to convert cellulosic biomass to ethanol and advanced biofuels." It is the only BRC housed primarily within academic institutions. The center is based at the University of WisconsinMadison in a major partnership with Michigan State University. Over the first 7 years, 16 additional institutions have been members of the center, with the number changing as individual projects are initiated or completed. The Wisconsin Alumni Research Foundation provides coordinated intellectual property portfolio management for GLBRC.

GLBRC targets two important knowledge gaps: sustainable biofeedstocks with desired traits for biofuels and efficient biomass conversion into fuels and chemicals. Sustainable processes are at the core of the GLBRC operating philosophy, and the center spends substantial effort to understand the 
environmental impacts of the biofuels value chain, from biomass production through combustion of the resulting fuel. The other three research foci, as with the other BRCs, involve understanding and modifying plant biomass, biomass deconstruction, and synthesis of fuels via microbial and chemical means. GLBRC has developed a pipeline to move research biofeedstock samples throughout the center and the downstream laboratory processes.

GLBRC has also focused on community education and outreach (E\&O). E\&O staff regularly speak at conferences and in classrooms locally and nationally, directly reaching over 3000 people per year. Many of these are educators who also train their colleagues in the programs that GLBRC provides. E\&O staff also regularly appear on Wisconsin Public Radio to discuss bioenergy issues. GLBRC web pages with information on our classroom materials and corresponding programming are currently receiving approximately 18,000 page views per year. The pages currently provide 25 classroom-vetted activities based on GLBRC research.

Joint Bioenergy Institute The Joint BioEnergy Institute (JBEI) is taking an integrated systems approach to address the roadblocks in renewable fuel production. JBEI draws on the expertise and capabilities of four national laboratoriesLawrence Berkeley National Laboratory (LBNL), Sandia National Laboratories (SNL), Lawrence Livermore National Laboratory (LLNL), and Pacific Northwest National Laboratory (PNNL) - and three leading US academic institutionsUniversity of California campuses at Berkeley (UCB) and Davis (UCD) and Carnegie Institution for Science - to develop the scientific basis for conversion of energy stored in lignocellulose into renewable biofuels. To facilitate collaboration and integration, JBEI has co-located nearly all researchers from the partner institutions in one location in Emeryville, $\mathrm{CA}$, and established an organizational structure that fosters cross-divisional research and use of JBEI-developed and other scientific tools to accelerate its feedstocks-to-fuels program.

JBEI's research program reflects the integrated nature of the feedstocks-to-fuels process, with a focus on the production of advanced biofuels that are "drop-in" replacements for gasoline, diesel, and aviation fuels. The JBEI research program is carried out by three scientific divisions that address the challenges associated with the production of advanced biofuels (Feedstocks, Deconstruction, and Fuels Synthesis) and a Technology Division. A multidisciplinary approach is required to address the challenges in converting biomass to renewable gasoline, diesel, and aviation fuels. For example, the tools developed by the Technology Division, such as the R\&D 100 award-winning nanostructure-initiated mass spectrometry (NIMS) platform technology [12, 13], have enabled highimpact science within JBEI, with the other BRCs, and with other external collaborators, in the screening of enzyme and microbial activities on lignocellulosic substrates [14, 15].
In addition to the core S\&T program, JBEI has developed a technoeconomic model for a biorefinery that helps researchers understand the economic impact of their work. JBEI's commercialization team actively licenses the intellectual property generated to companies and promotes the creation of start-up ventures around the most promising discoveries. In addition, JBEI has a strong public and educational outreach program that educates high school, undergraduate, and graduate students, post-doctoral fellows, and the general public and, as such, is populating the workforce and academia with trained biofuel experts. Collectively, JBEI's integrated research approach, co-located staff, and commercialization strategy provides the science, technology, and translational mechanisms to enable industry to bring advanced fuels to market.

\section{Support from the US Department of Energy}

Each center received $\$ 10 \mathrm{M}$ of start-up funding and $\$ 25 \mathrm{M}$ per year for the first 5 years. Additional in-kind support was generally provided to each center by their sponsor institutions and state sources. A portion of this funding was used by each BRC to establish unique core computational and wet lab facilities to support the specific science within each research portfolio and to fund administrative positions. An additional $\$ 13.5 \mathrm{M}$ in equipment support was provided from the American Recovery and Reinvestment Act of 2009 (ARRA). Links among the centers eventually led to collaborations that provided core services to scientists across all BRCs. The centers were renewed for a second 5-year term in 2012, again at \$25 M per year.

In addition, all three centers have established a close relationship with DOE's Joint Genome Institute (JGI), based in Walnut Creek, CA (see below). JGI is a DOE User Facility that provides a range of capabilities for genome sequencing, metagenomics, transcriptomics, DNA synthesis, and associated bioinformatics. BER enabled this relationship through allocation of a specific fraction of JGI sequencing capacity to each BRC, and this allocation allowed the BRCs to consider very large sequencing projects that could target core questions in biofuel technology development. Founding of the BRCs approximately coincided with the emergence of nextgeneration sequencing, particularly 454 and Illumina technologies, and the subsequent rapid decrease in sequencing costs. Therefore, each center's allocation increased significantly over the initial funding period, as these technologies became established at the JGI. An early agreement among the BRCs permitted JGI to dynamically balance the requested sequencing bandwidth across all centers, depending on quarterly demand. Thus, when a particular BRC requested less sequencing bandwidth than allotted in a particular quarter, it was made available to other BRCs. This process was facilitated by several cross-BRC 
projects on plant genomes (particularly switchgrass) that relied heavily on sequencing resources.

All three BRCs were renewed in late 2012 for an additional 5 years, and DOE has reiterated its support of basic research for sustainable bioenergy [16]. This renewal has permitted continued exploitation of the infrastructure and relationships established in the first 5 years and supports continued focus on sustainable production of lignocellulose-derived fuels. The renewal extends the productive relationship between the BRCs and JGI, including joint projects on the switchgrass genome, biomass pretreatment, and glycohydrolase enzymology.

The funding remained flat in the second 5 years, at $\$ 25 \mathrm{M} /$ year/center. Fortunately, inflation has been low, averaging about $1.5 \%$ over the first 7 years [17], meaning that budgets have declined by only about $10 \%$ in real dollars over the period. All centers have consistently leveraged DOE funding with other sources, including funding from the institutional hosts, fellowships, and complementary grants. In addition, although the rapid decrease in sequencing costs has slowed, at least temporarily, nascent technologies are expected to continue the general downward trend and increased capacity. JGI's continued work at the forefront of functional genomics remains an essential tool for increasing productivity.

\section{JGI Capabilities and Collaborations with the BRCs}

The Joint Genome Institute (JGI) is a genomics user facility funded by DOE's Office of Science to produce genomes and analysis of relevance to alternative energy production, global carbon and nutrient cycling, and biogeochemistry. JGI was formed to participate in sequencing of the human genome, and following completion of that project, JGI made the transition to become a user facility carrying out high-throughput sequencing and analysis, now serving more than 1200 users annually. From the inception of the BRCs in 2008, JGI has devoted $30 \%$ of its annual effort to them and prioritized their projects. JGI's annual sequencing performed for the BRCs has increased more than 100 -fold from $270 \mathrm{~Gb}$ in 2009 to $28 \mathrm{~Tb}$ in 2014 (Fig. 1). This increase was driven primarily by a $>90$ fold reduction in the cost of next-generation sequencing.

JGI is more than a DNA sequence producer, having developed a number of specialized pipelines not widely available elsewhere. For example, JGI is the world leader in the sequencing and analysis of complex plant genomes and used this expertise for sequencing of bioenergy crops that the BRCs have leveraged in their work: Populus trichocarpa, S. italica, Brachypodium distachyon, and, more recently, $P$. virgatum (switchgrass) and its diploid relative, Panicum hallii (all available at www. Phytozome.net). Consistent with this focus on bioenergy-related "flagship" genomes, JGI developed additional tools and strategies of special interest to the BRCs including large-scale genotype-by-sequencing and exome

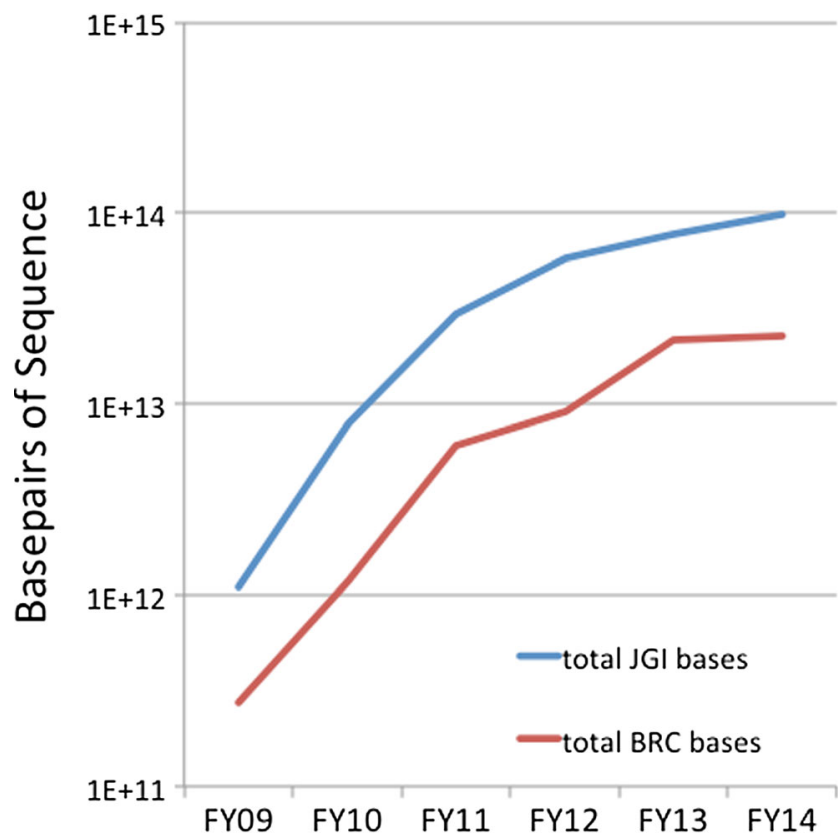

Fig. 1 Nucleic acid sequencing by JGI in support of BRC projects through 2014. The total number of sequenced base pairs produced by the JGI for the BRCs (red line) relative to the total number of base pairs sequenced (blue line). Note the logarithmic scale on the vertical axis. $F Y$ on the horizontal axis refers to JGI's fiscal year (October-September)

capture strategies to characterize variation within a population. These are now being applied at scale in poplar, maize, rice, and switchgrass.

Similarly, the JGI has robust pipelines for microbial and metagenome sequencing that are routinely employed by the BRCs. Since full-scale deployment of the Illumina short-read sequencing platform in 2011, JGI produced more than 200 bacterial genomes, 33 fungal genomes, 400 metagenomes, and completed more than 2200 resequencing experiments.

In 2012, JGI published a 10-year Strategic Vision, and a central element of that vision is the development of new capabilities that enable functional interpretation of genomic data. Chief among these is the ability to write DNA in addition to reading it. JGI now produces $>4 \mathrm{Mb}$ of synthetic DNA annually, and nearly $50 \%$ of this is consumed by BRC projects. This allows the BRCs to mine genome and metagenome sequences for activities of interest and alter them for expression and testing as was the case for a large collection of GH1 enzymes tested for IL, $\mathrm{pH}$, and temperature tolerance. JGI also has developed CRISPR/Cas9 genome editing technology, high-throughput transposon mutagenesis, and metabolomic capabilities that are now at the disposal of the BRCs.

\section{The BRCs and Key Scientific and Engineering Challenges in Lignocellulosic Biofuel Production}

The core function of the BRCs is to provide basic research that addresses the primary challenges to developing 
a sustainable liquid biofuel industry. The research portfolio of each center is built around these challenges, with complementary, and often collaborative, approaches taken. The key challenges identified by the centers during the first years include the following:

\section{Biomass supply and sustainability}

- The environmental, social, and economic sustainability of growing and collecting biomass for biofuels must be thoroughly evaluated to permit data-driven policy decisions in both the public and private sectors.

- Sources of "residual" non-food lignocellulosic biomass are diverse and dispersed, biomass is generally low-density, and there is no established supply chain for collecting, transporting, and delivering this material to biofuel facilities.

\section{Bioenergy crop optimization}

- In contrast to crops used for food and fiber, there are no crops that have been developed specifically for use as cellulosic biofuel feedstock. Identification of optimal agronomic properties, plus additional fundamental knowledge of plant cell wall synthesis and structure, can enable production of optimized crops.

- Programs for optimizing plant oils for biofuel applications, and producing oils within the vegetative tissues of plants, promise to make energy-dense oils more readily available as biofuels or biofuel feedstocks.

\section{Deconstruction of biomass}

- Deconstruction of lignocellulosic polymers to yield useful small molecules at low costs is the primary technical barrier to economical liquid biofuels. Scalable, sustainable, and affordable processes must be developed to handle diverse feedstocks at low cost. These technologies are expected to fall into these categories: biomass pretreatment followed by enzymes, consolidated bioprocessing, direct chemical deconstruction of biomass into fermentable sugars, and hybrid biochemical and thermochemical unit operations to deconstruct biomass.

- The three centers have focused on different, and complementary, core technologies for pretreating biomass and generation of fermentable sugars. GLBRC focuses on alkaline pretreatments, including ammoniabased and hydrogen peroxide-based pretreatments. JBEI has focused on ionic liquids and on identifying enzymes and microbes that can tolerate these compounds, and BESC has utilized dilute acids and focused on minimal or hot water pretreatments.

\section{Conversion of biomass to fuels}

- Reaching the biological limits in ethanol production from cellulosic polysaccharides including minimizing inhibition, fermenting multiple sugars, and consolidated bioprocessing.

- Conversion of sugars to non-ethanol liquid fuels, through either biological or chemical routes, must be made more energy-efficient and economical.

- Lignin is approximately one third of biomass by weight, and the valorization of lignin beyond burning for heat will make lignocellulosic fuel technologies more cost-competitive by effectively utilizing the lignin for chemicals or fuels.

\section{Biomass Supply and Sustainability}

GLBRC is the BRC most focused on sustainability of biomass production, taking advantage of the strong agricultural programs at both UW-Madison and MSU. A primary goal is to understand the underlying factors responsible for environmental sustainability of biomass production, and how socioeconomic factors like costs and the differing priorities of landowners will affect adoption of the most sustainable practices. Sustainability research at GLBRC focuses on the following: (1) novel production systems; (2) microbe-plant interactions; (3) biogeochemical processes; (4) biodiversity services; (5) economic services; and (6) biophysical, economic, and life cycle modeling. The modeling group draws on data generated by the other groups.

A good example of how modeling builds on the work of other BRC scientists is included later in this issue [18]. This life cycle assessment builds on data generated from field experiments, pretreatment, deconstruction, and fuel synthesis from the BRCs and many other sources to comprehensively assess the environmental impact of eight ethanol production scenarios in Michigan and Wisconsin. The research shows the importance of including specific agricultural practices and spatially explicit data in modeling efforts. Field research generated by GLBRC sustainability scientists is specifically designed to provide the knowledge necessary for these types of modeling efforts.

BESC has shown that the switchgrass rhizosphere can be altered by specific fungal colonization to increase biomass yield in the greenhouse under both normal water and drought conditions [19]. BESC is also examining key nutrient uptake parameters in switchgrass. In order to capture and understand the power of range of natural variation in 
Populus biology, BESC established common gardens with a thousand replicated individuals in three environmental locations. While the biological goals were for improved biomass (discussed below), BESC now has over 3 years of growth data for this population with evidence for adaptation under selective pressure [20].

\section{Biomass Crop Optimization}

GLBRC has focused on understanding the basic biochemistry of plant cell wall synthesis so that the knowledge can be applied to optimize plants as biofuel feedstocks. The Center has put particular focus on the modification of lignin to make it more easily deconstructed, thereby reducing costs and increasing sugar yields. The main concept is to introduce large numbers of ester bonds, which are significantly more labile than the normally abundant ethers, into the lignin backbone (socalled, Zip-Lignin ${ }^{\mathrm{TM}}$. The key has been identifying the enzymes necessary to make monolignol ferulate conjugates and expressing them in the proper locations for incorporation into the growing lignin chain.

Transcript profiling in collaboration with JGI led to identification of putative feruloyl monolignol transferase (FMT) genes in Angelica sinensis, balsa, and kenaf [21-23]. Characterization of proteins expressed from the cloned genes showed the appropriate activity with feruloyl-CoA, with very low reactivity on potentially competing substrates [23]. The first generation of engineered poplar expressing FMT showed significantly increased ferulate in the lignin, and the engineered biomass is significantly more easily degraded. Moreover, the plants appear to grow normally, as compared to the nontransgenic controls. The center is currently engineering additional lines and proceeding toward field trials of the modified poplar in order to provide sufficient material for large-scale testing as a biofuel feedstock.

BESC focused on two approaches for understanding and improvement: cisgenic manipulations and exploiting natural variation. These were carried out in potential biofeedstocks; switchgrass (Panicum virgatum) as a perennial grass and several Populus species as a fast-growing woody plant. The primary goal was to decrease recalcitrance. These studies required development of a series of new platforms to analyze the thousands of resulting plant samples for composition, pretreatment, and saccharification [24]. This cisgenic genetic engineering has shown that lignin can be manipulated at both the gene and the pathway level to decrease recalcitrance $[25,26]$. It has also been demonstrated that manipulation by knockdown or overexpression of cellulose and of xylan can also decrease recalcitrance. Unexpectedly, manipulation of pectin formation such as by the GAUT genes will also improve saccharification, even though pectin is a very small component of the secondary plant cell wall $[27,28]$. Further evidence of the importance of pectin in the structure and accessibility of biomass comes from the use of a cellulolytic microorganism which had a pectinase gene cluster deleted and was deficient in its ability to degrade normal complex lignocellulosic biomass [29]. This research is a good example of the crossdisciplinary work made possible through the BRCs.

Another long-standing concern for low recalcitrance biofeedstocks is their durability in the field. BESC now has 1 to 3 years of field data for various switchgrass transgenics showing not only survival for many (but not all) greenhousetested lines, but also equal or better growth along with lowered recalcitrance [30]. This collaborative effort indicates that a "better biofeedstock," with the combined goals of good agronomic characteristics and improved conversion, is possible [31].

Likewise, the natural variation in both recalcitrance and in growth has been observed. The largest genome-wide population association study (GWAS) to date involves over a thousand Populus tricocarpa individuals planted in several environments. These individuals were resequenced by JGI and now provide a resource for numerous growth characteristics as well as measurements in composition [32]. With over 3 years of observations, several of the lines have shown greatly reduced recalcitrance on par with the best field transgenics. BESC also has efforts with natural variation in switchgrass and with transgenic manipulations in Populus sp.

Sequencing the switchgrass genome has been a collaboration among all three Bioenergy Research Centers, JGI and the switchgrass research community. Foxtail millet (Setaria italica) was sequenced as a template and scaffold for the $P$. virgatum genome [33]. A first draft of the genome was completed and work is proceeding on a second draft to be released by JGI. This data resource has included a large number of ESTs [34].

At JBEI, researchers in the Feedstocks Division have made breakthroughs in the discovery and characterization of key enzymes controlling cell wall biosynthesis and modification in the model plants Arabidopsis and rice. The identified enzymes include acetyl and feruloyl transferases involved in hemicellulose modification [35-37] and several enzymes involved in hemicellulose and pectin biosynthesis [38-41]. Among the enzymes identified are two novel glycosyl transferases involved in adding side chains to xylan, the most abundant non-cellulosic polysaccharide in biomass [39]. Modulating the expression of these glycosyl transferases, as well as the acetyl and feruloyl transferases, led to substantially improved saccharification. A key objective of JBEI is to develop technologies and resources to rapidly advance the understanding of cell wall biosynthesis. In collaboration with the Technology Division, the Feedstock Division has cloned nearly $90 \%$ (400 out of 450) of the glycosyltransferases genes in Arabidopsis, as well as about $15 \%$ of those encoded by the rice genome [42]. All clones have been validated as full coding sequences and are available as a collection to the 
community in functional genomic compatible vectors for high-throughput functional assays, clones are available from public resources (e.g., ABRC,) and updates to the collection can be found at http://gt.jbei.org/. The collection represents an ongoing commitment by JBEI to provide resources to the plant research community to fast-track the development of future biofuel crops. Novel transcription factors, as well as nucleotide sugar transporters and interconverting enzymes that impact cell wall composition, were identified [39, 43, 44]. JBEI scientists have developed and validated highly effective procedures for cell-specific genetic engineering in plants, and using novel engineering strategies, JBEI researchers have generated plants with altered cell wall composition [45, 46]. Altering the lignin composition, or its spatial distribution, makes a significant impact on biomass deconstruction.

Based on these discoveries in model plant systems, JBEI has made significant progress in trait translation from model species (rice and Arabidopsis) to potential biofuel crop by engineering switchgrass plants with the lignin polymerization reduction and low ferulate traits previously described in Arabidopsis and rice, respectively [47, 48]. This includes a demonstration that switchgrass lines overexpressing the rice OsAT10 acyltransferase have a $40 \%$ increase in saccharification yield following mild pretreatment (hot water, $100^{\circ} \mathrm{C}$ for $1 \mathrm{~h}$ ). Recently, these lines were characterized using ionic liquid (IL) pretreatment and enzymatic saccharification. Unlike the results using hot water, glucose yields in IL-treated OsAT10 overexpressing lines positively correlated with enhanced ferulic acid and $p$-coumaric acid content. Analysis of transgenic switchgrass plants expressing key rice stress genes, wall-associated kinase- 25 , and cell wall regulatory proteins is underway. In order to improve success in switchgrass engineering, JBEI generated a series of 12 binary vectors for secondary cell wall expression. Several of them are already in process to be tested in switchgrass and validated with lignin engineering strategies.

\section{Biomass Deconstruction}

As part of an effort to better understand natural biomass deconstruction systems, GLBRC collaborated with JGI to obtain the genome sequences of more than 25 novel biomassutilizing organisms from a diversity of ecological niches. Although these genomic sequencing efforts offer extensive lists of genes annotated as potential polysaccharide-degrading enzymes, further biochemical and functional characterizations of the encoded proteins and accompanying pretreatment research are needed to realize the full potential of this natural genomic diversity. To improve the understanding of the relationships between sequence and function in the biofuels phylogenetic space, a collaborative project among JBEI, GLBRC, and JGI combines state-of-the-art gene synthesis, robotic cell-free protein translation, multiplexed functional analysis, and structure determination.

Deconstruction researchers are interested in multifunctional enzymes and how they might be used to simplify the composition of enzyme cocktails. GLBRC researchers using biochemical assays, X-ray crystallography, substrate docking, and mutagenesis discovered that CelE was a multifunctional enzyme [49]. Ongoing collaborative work between GLBRC and JBEI using oxime derivatization of products and detection by NIMS at JBEI is yielding a unique time-resolved picture of biomass deconstruction by engineered CelEcc_CBM3a and other enzymes [14]. For IL-pretreated switchgrass, monosaccharides and oligosaccharides derived from both cellulose and hemicellulose can be simultaneously detected, accounting for more than $50 \%$ yield of soluble sugars at relevant enzyme/ biomass loadings. The time course of these reactions can be modeled by the kinetic schemes shown using numerical simulation, providing a new approach to quantitative modeling of the rate-limiting steps in biomass deconstruction.

GLBRC researchers used CelE as a phylogenetic anchor then performed multiple sequence alignments curated with experimental information to identify 65 other putative multifunctional enzymes from metagenomes, uncultured bacteria, and some known organisms (unpublished results). Colleagues at JGI successfully synthesized 57 of the corresponding genes, and 56 were expressed using GLBRC's high-throughput robotic protein production platform. Among these newly expressed proteins, 40 showed activity with at least one substrate (cellulose, lichenan, xylan, mannan), and 12 enzymes reacted with all substrates tested. Catalytic constants, $\mathrm{pH}$ optima, and thermal stability show a remarkable range, thus offering many new opportunities for assembly of customized enzyme cocktails. Further evaluations of these enzymes are underway by scientists in the GLBRC and JBEI.

At JBEI, researchers in the Deconstruction Division began addressing the challenges in developing an effective approach for pretreating biomass and comparing different pretreatment techniques. The IL pretreatment process with imidazoliumbased ILs, such as 1-ethyl-3-methylimidazolium acetate $\left(\left[\mathrm{C}_{2} \mathrm{C}_{1} \mathrm{Im}\right][\mathrm{OAc}]\right)$, was found to consistently provide higher yields of fermentable sugars than those resulting from other pretreatment technologies, such as dilute acid [50] and ammonia fiber expansion (AFEX) [51]. The IL pretreatment method developed at JBEI provides up to $90 \%$ recovery of the IL [52] and a readily hydrolyzable solid product. JBEI has shown that this IL process can also efficiently pretreat hardwoods, softwoods, grasses, and agricultural residues and generate high yields and concentrations of fermentable sugars using both commercial cellulase enzymes and enzymes developed at JBEI $[53,54]$. JBEI researchers also developed a technoeconomic model of biofuel production using the IL pretreatment technology to benchmark progress in terms of cost and process efficiency [55]. The key to an economically viable 
and scalable IL pretreatment technology is to develop efficient and cost-competitive processes to recover sugars and lignin and recycle IL for reuse. JBEI has developed and tested several IL recycle and recovery strategies. The investigators have demonstrated an improved liquid-liquid membrane extraction method that recovers $>90 \%$ glucose and $>95 \%$ xylose at ambient temperature, and the recycled IL retains $>95 \%$ of its original pretreatment efficiency. Additionally, JBEI evaluated membrane (micro-, ultra-, and nano-) filtration and electro-dialysis separation technologies in conjunction with newly developed "one-pot" IL pretreatment and saccharification process $[56,57]$.

Imidazolium-based ILs effectively pretreat biomass and generate high yields of fermentable sugars from a wide range of biomass feedstocks. However, the best performing ILs are derived from non-renewable sources such as petroleum. Researchers at JBEI reported on the first of its kind synthesis and evaluation of a series of ILs from monomers obtained from lignin and hemicellulose [58]. Reductive amination of the lignin and hemicellulose-derived aromatic aldehydes followed by treatment with phosphoric acid provided three ILs in excellent yields. Enzymatic saccharification with two of these renewable "bionic liquids" provided 90 and $96 \%$ of total possible glucose and 70 and $76 \%$ of total possible xylose, respectively, after biomass pretreatment. It is hypothesized that the mechanism of action of the lignin and hemicellulose-derived ILs is therefore more akin to other biologically derived ILs, such as ILs prepared from choline. Glycome profiling experiments conducted in collaboration with BESC further suggested that the new bionic liquids act on plant cell walls by a mechanism distinct from $\left[\mathrm{C}_{2} \mathrm{C}_{1} \mathrm{Im}\right][\mathrm{OAc}]$. These results show significant potential for the realization of a "closed-loop" process for future lignocellulosic biorefineries [58].

In addition to the core IL pretreatment technology, JBEI researchers have also been working on developing IL-tolerant enzymes and microbes. In collaboration with JGI and the Environmental Molecular Sciences Laboratory (EMSL) at PNNL, expression of thermotolerant cellulases from a switchgrass-adapted metagenome identified a number of endoglucanases and $\beta$-glucosidases that were active in $\leq 40 \%\left[\mathrm{C}_{2} \mathrm{C}_{1} \mathrm{im}\right][\mathrm{OAc}]$, including cellulases that had higher activities in the presence of IL [59]. These metagenomederived enzymes have been used in developing purified thermo/IL tolerant cellulase mixtures by the Enzyme Optimization group. Comparative metagenomics were used to identify acellobiohydrolases (GH48s) present in thermophilic solid-state rice straw microbial communities that are also being tested by the Enzyme Optimization group [60]. Comparative proteomics in collaboration with EMSL with celluloseadapted communities revealed that the level of GH12 in the supernatant was a critical determinant for activity on crystalline cellulose, an unexpected result as GH12 is an endoglucanase and the levels of the canonical exoglucanases, GH48 and GH6, as well as the AA10 protein (CBM33) did not correlate with increased activity on crystalline cellulose. Heterologous expression of a minimal cellulase mixture from Thermobispora bispora is being performed to understand the role of GH12 in hydrolysis of crystalline cellulose.

BESC has targeted consolidated bioprocessing (CBP) which attempts to combine biomass deconstruction and conversion to fuels into one step. With CBP, BESC has attempted to move from dilute acid pretreatment to hot water and even to only autoclaving as a minimal pretreatment. BESC attempted two strategies: to add cellulolytic capabilities to a good ethanologen (i.e., yeast) and to modify native cellulolytic fermentative microorganism into good fuel producers [61, 62]. The work has focused on cellulolytic thermophiles because of the high rates of biomass consumption [63]. It has greatly improved genetic tools for Clostridium thermocellum and developed tools for Caldicellulosiruptor sp. [64].

The use of genetically engineered and evolved mutants of C. thermocellum was combined with resequencing and other omics experiments to provide insights on ethanol tolerance. A mutation in the alcohol dehydrogenase gene, $a d h E$, conferred a significant ethanol tolerance phenotype to $C$. thermocellum [65-67]. Further biochemistry showed that one of the effects of this mutation was a change of redox co-factor specificity from NADH to NADPH. This further supports the view of the importance of redox pathways in these fermentations, as well as in the metabolic modeling.

While pretreatment still improves conversion, significant conversion can nevertheless occur with minimal pretreatment using a naturally cellulolytic microorganism [68]. This appears to be linked to the mechanisms of enzymatic attack by cellulolytic enzymes of these thermophiles [69]. The primary cellulase from Caldicellulsiruptor, CelA, was shown to be the most efficient enzyme for cellulose degradation [70].

While the three centers have different deconstruction strategies, a collaboration between the three BRCs has developed to compare and contrast the three different core conversion technologies. By using a single common feedstock (e.g., corn stover) and using consistent analytical protocols, the crossBRC pretreatment collaboration has provided new insights in the mechanisms and impacts of the three different classes of pretreatment [51, 71-73]. The resulting series of papers form the foundation of an ongoing collaboration that will expand into evaluation of selected and engineered feedstocks in order to establish a genotype-phenotype relationship that covers the fuels-to-feedstock pipeline at all three BRCs.

\section{Conversion of Biomass to Fuels}

In addition to the ethanol CBP research above, BESC has shown that fuels other than ethanol can be produced by CBP. This involves the addition of the isobutanol pathway 
into a cellulolytic Clostridium [74]. Engineered CBP microbes such as $C$. thermocellum can be combined with engineered plants (the RNAi knockdown of catechol- $O$-methyltransferase in switchgrass) with an additive improvement in the conversion and ethanol production [75].

The primary research goal of JBEI's Fuels Synthesis Division is to identify challenges and develop approaches to enable engineering of microorganisms to efficiently convert sugars to advanced biofuels with properties similar to petroleum-based fuels. To that end, fuel synthesis pathways based on the fatty acid, isoprenoid, polyketide, and aromatic amino acid biosynthetic pathways were developed. These pathways are being engineered into one or both of two host organisms: Escherichia coli and Saccharomyces cerevisiae. Because yields and productivities must be high to make production of biofuels economically viable, researchers engineered central metabolism in these two host strains to deliver precursors to the biosynthetic pathways. This requires new computer-aided design software and genetic tools to control expression of the genes and metabolic models to identify pathway constraints.

JBEI researchers are engineering $S$. cerevisiae to produce fatty acid-derived fuels by overexpressing $A C C 1, F A S 1$ and $F A S 2, D G A T$, and TesA [76]. In prior work, JBEI achieved free fatty acid titers of greater than $400 \mathrm{mg} / \mathrm{L}$. JBEI researchers made pathway and host engineering modifications to $E$. coli strains bearing a novel pathway for biosynthesis of $C_{11}$ to $C_{15}$ methyl ketones [77]. These modifications resulted in a 160fold increase in titer in minimal medium $(1 \%$ glucose) relative to the best strain reported in 2012, with attainment of a yield that is $40 \%$ of the maximum theoretical value and a titer of $3.4 \mathrm{~g} / \mathrm{L}$ in $45 \mathrm{~h}$ in fed-batch fermentation. These are the highest titers and yields of methyl ketones (other than acetone) yet reported in engineered or native bacteria. Bisabolane (reduced $\alpha$-bisabolene; cetane number of 52.6) is a promising diesel and bio-jet fuel candidate [78]. JBEI researchers have engineered the bisabolene-producing $E$. coli and $S$. cerevisiae strains to achieve titers of $\sim 3.5$ and $\sim 6 \mathrm{~g} / \mathrm{L}$, respectively. Researchers at JBEI have engineered $E$. coli to produce the terpenoids limonene and $\alpha$-pinene, by expressing genes encoding codon-optimized geranyl diphosphate (GPP) synthase and Abies grandis limonene synthase (for limonene) and pinene synthase (for pinene). Limonene titers were improved from 50 to $450 \mathrm{mg} / \mathrm{L}$ through metabolic engineering efforts [79] and have been further improved to $600 \mathrm{mg} / \mathrm{L}$ by balancing the pathway from the analysis of proteomics data.

JBEI has also developed synthetic biology tools to enable the entire R\&D community. One example of these software tools is the Design, Implementation, Validation Automation (DIVA) software. JBEI released DIVA v1.7.0 and initiated the DIVA PCR Service for researchers. Over 75 designs have been submitted to the DIVA PCR Service by Deconstruction, Fuels Synthesis, and Technology Division scientists at JBEI.
Both the JGI and the DNA Foundry at the University of Edinburgh have now adopted DIVA. Another example of these software tools is the Inventory of Composable Elements (ICE) repository software. JBEI released ICE v4.0.0 [42, 80], which offers improvements including the following: (1) hierarchical DNA components: enables ICE entries to be capable of containing other ICE entries; (2) audit log: maintains activity information (e.g., view and edit) on each ICE entry; (3) private remote collaboration: enables members of an ICE instance to privately share, through the "Web of Registries," their entries with members on a different ICE instance; and (4) bulk upload improvements: performance improvements to allow larger numbers of entries to be uploaded and more "Excel-like" interface features such as "click to drag" and "copy/paste." Furthermore, ICE has been integrated with JBEI's Experiment Data Depot (EDD). In support of the DIVA platform and PCR Service, JBEI developed j5 [81] to output PR-PR [82] scripts for split-and-pool PCR reactions (crucial to the success of Quick Change and one-part circular polymerase extension cloning (CPEC) reactions) as well as to output PR-PR scripts for DNA assembly reactions.

GLBRC has been particularly interested in the roles played by various small-molecule inhibitors during biofuel synthesis by microorganisms. These inhibitors may be produced during biomass pretreatment and are therefore often process-specific [83-85]. But, the fuels themselves can also be inhibitory, and understanding the nature of this inhibition is essential to identifying compensatory measures. For example, GLBRC scientists showed that, at least in E. coli, ethanol toxicity largely results from inhibition of "central dogma" processes of transcription and translation [86]. These results, obtained through isolation of ethanol-resistant mutants and sequencing in collaboration with JGI, highlight the many ways in which organisms may be optimized to improve the rate and yield, and reduce the cost, of fuel production from biomass.

In GLBRC, considerable progress has been made on chemical catalysis for biomass-to-biofuel conversion. Bypassing enzymatic hydrolysis to liberate sugars from biomass offers significant cost-savings, but the cost of catalysis and solvents used in chemical deconstruction is also significant. GLBRC researchers have taken two primary routes to chemical conversion to address these hurdles.

The first route relies on decrystallization of cell wall carbohydrates in ILs, followed by acid-catalyzed hydrolysis in the presence of water [87]. In the absence of water, the glucose rapidly degrades to hydroxymethyl furfural (HMF), but careful addition of water to the reaction results in glucose yields approaching $90 \%$ with low HMF production. The products and solvents can be separated by simulated moving bed chromatography to recover approximately $99 \%$ of both classes of products [88]. The second route uses gamma valerolactone (GVL) to dissolve biomass and low concentrations of mineral acids to release sugars and to promote the dehydration of 
glucose and xylose to levulinic acid (LA) and furfural, respectively [89-91]. These two important platform chemicals can be upgraded to value-added compounds or biofuels $[92,93]$. Furthermore, LA can be catalytically converted to GVL, which can be recovered by phase separation using liquid $\mathrm{CO}_{2}$ or salt. Both the GVL and the mineral acid can be recycled and used for further rounds of biomass deconstruction and catalysis, thus lowering the costs of materials and their environmental impact [94].

Lignin comprises up to one third of biomass and $40 \%$ of its latent energy. Unlike carbohydrate polymers, which are degraded by direct binding of catabolic enzymes, lignin is a heterogeneous aromatic complex that is naturally degraded primarily through reactive oxygen species produced by microbial laccases and peroxidases $[95,96]$, although there is evidence that some bacterial species directly attack lignin anaerobically by using it as a terminal electron acceptor [97]. These indirect mechanisms have been difficult to mimic at high yield in the laboratory, but GLBRC scientists recognized that lignin's $\beta-O$ 4 linkages, which contain a secondary benzylic alcohol and a primary aliphatic alcohol, might be attacked. They demonstrated chemoselective oxidation of the benzylic alcohol using both model compounds and intact lignin [98] and showed that the products could be depolymerized in the presence of formic acid to generate defined aromatic fragments [99].

\section{Summary of Scientific and Technological Output over the First Seven Years}

The overall scientific output of the three BRCs is shown in Fig. 2, and the number of citations to BRC papers from a

Fig. 2 Total peer-reviewed publications by the BRCs through the first 7 years of operation. The number of manuscripts by each center for each year of operation is delineated within each bar particular year, as of the end of 2014, is shown in Fig. 3. For clarity, we report the publications on a calendar year basis, not on the funded federal fiscal year (October to September). The full bibliographies of each BRC used for this analysis are provided in the Supplemental Materials. In the first 7 years, the three centers published nearly 1900 peer-reviewed manuscripts. While there was a lag period after the founding of each center, all reached a steady state by about the third year, with a combined publication rate of just under six manuscripts per week. The BRCs consistently publish in top-tier journals within ISI's various technical domains and have published 184 manuscripts (approximately $10 \%$ of all papers) in elite journals, defined in this case as having ISI impact factors higher than 9. Thus, the overall quality of the science, as judged by peer reviewers and citation rates, appears to be very high.

The purpose of forming centers was to promote integrative projects capable of attacking biofuel research from multiple angles. All centers hired scientific and non-scientific staff specifically tasked with integration and developed operating philosophies consistent with this goal. Figure 4 illustrates how rapidly integration proceeded in GLBRC, and it is exemplary of the process at all three BRCs. The figure delineates manuscripts co-authored by scientists from different funded projects over the first 3 years, demonstrating the rapid rise in connections between groups. Similarly, Fig. 5 delineates the fraction of collaborative papers from GLBRC in each of the first 6 years. Likewise, an analysis of all publications from BESC shows that $35 \%$ are multi-institutional. Through all centers, there is a clear trend away from single-laboratory papers and toward collaborative work.

The JGI relationship not only supported many projects within each BRC, but also enabled large cross-BRC

\section{Total BRC Publications 2008-2014}

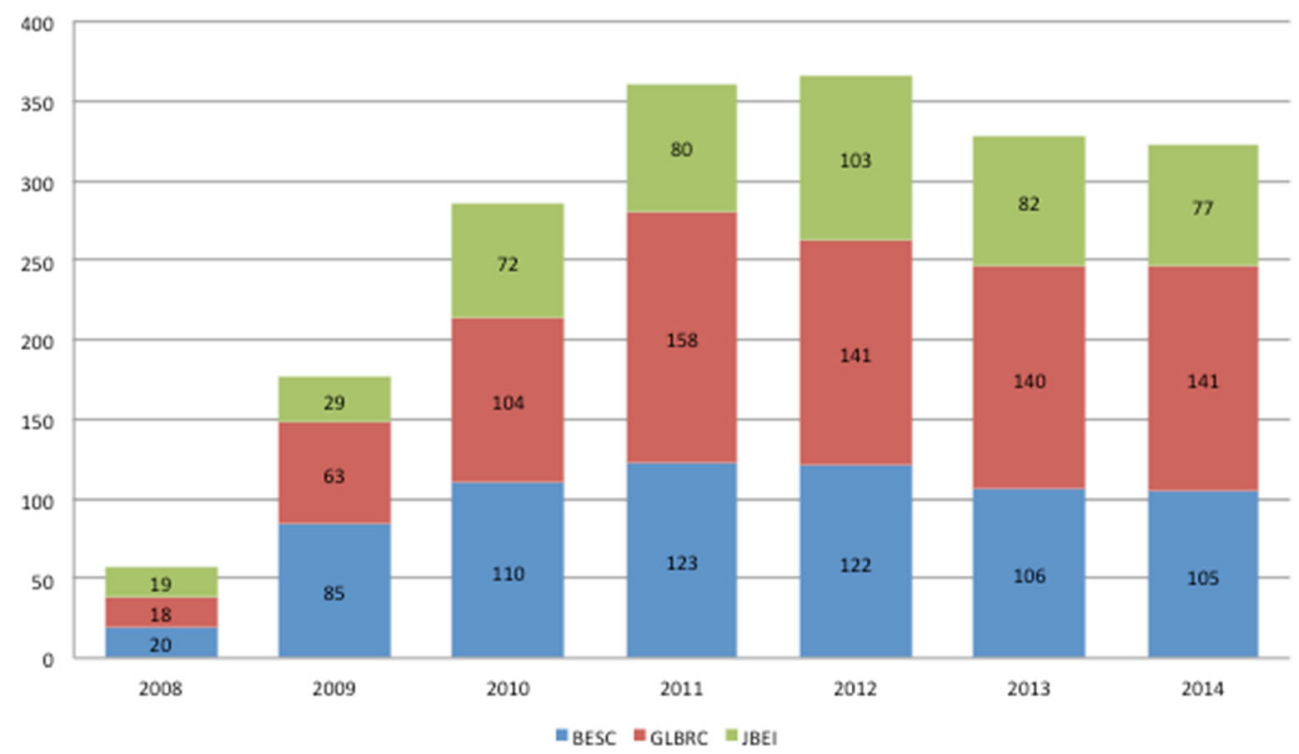


Fig. 3 Total citations to BRC manuscripts. Each bar shows the number of citations to papers published within that year, as of the end of December, 2014

\section{Total BRC Citations 2008-2014}

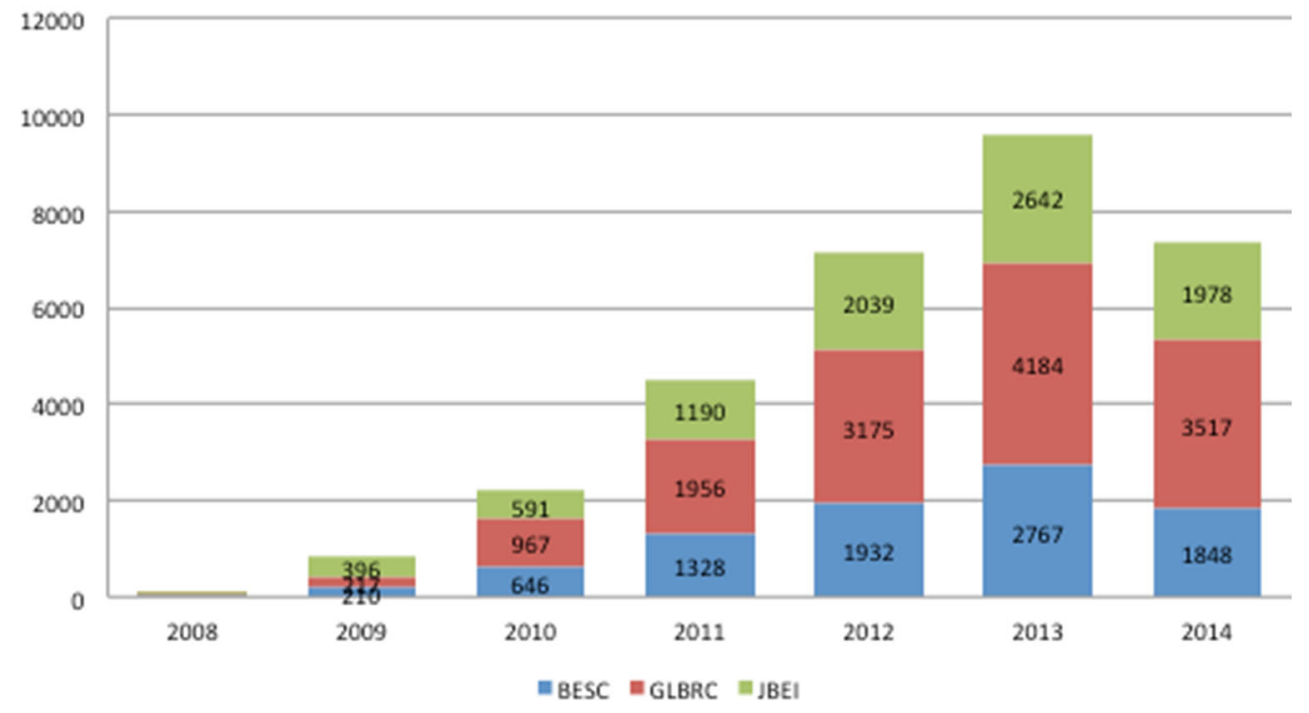

collaborations. For example, the BRCs and JGI agreed to collaborate on the switchgrass genome project, with each BRC allocating sequencing capacity and significant internal

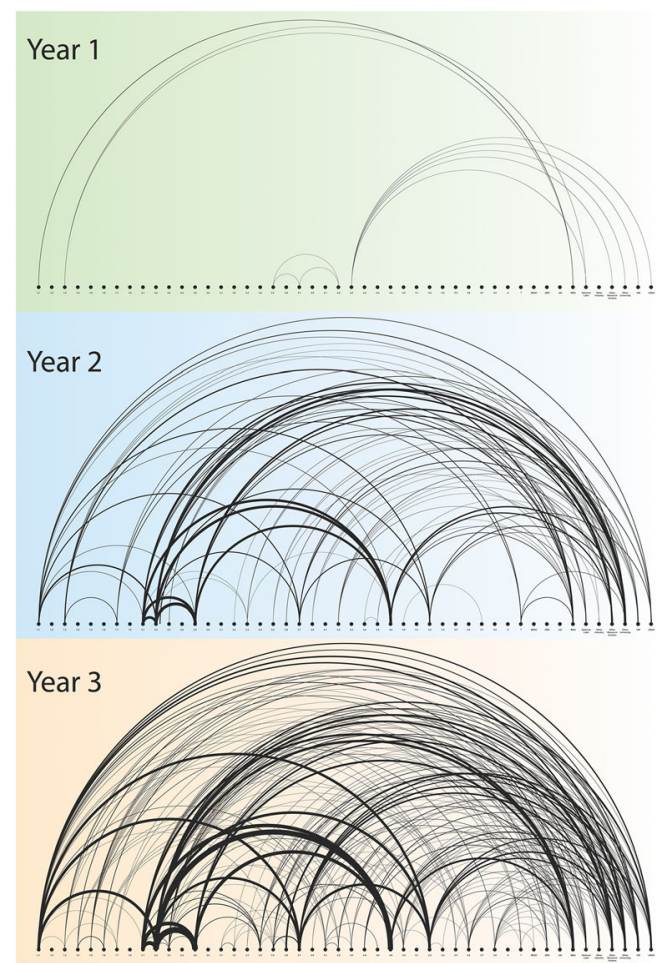

Fig. 4 Increase in inter-lab collaborations in GLBRC as measured by collaborative publications, over the first 3 years. Each point along the bottom of each year's figure represents one laboratory, and each arc represents a publication involving two labs. The ten dots at the right represent institutions outside of GLBRC, including JGI, JBEI, and BESC. Publications with more than two labs collaborating have multiple arcs, so the number of arcs does not correspond to the number of publications in a particular year resources. Over the past few years, JGI has added DNA synthesis to its repertoire, enabling an ongoing, multi-institutional project to express and catalytically characterize biomassdegrading enzymes. The cumulative result has been more than 50 high profile joint BRC-JGI publications, with many more in progress.

The BRCs have also consistently generated intellectual property, including over 400 patent disclosures, nearly 250 patent applications, and over 100 licenses of technology.

\section{BRC Research Highlighted in this Issue of BioEnergy Research}

This issue of BioEnergy Research provides a sampling of the work performed by the BRCs. If there is any single theme, it is

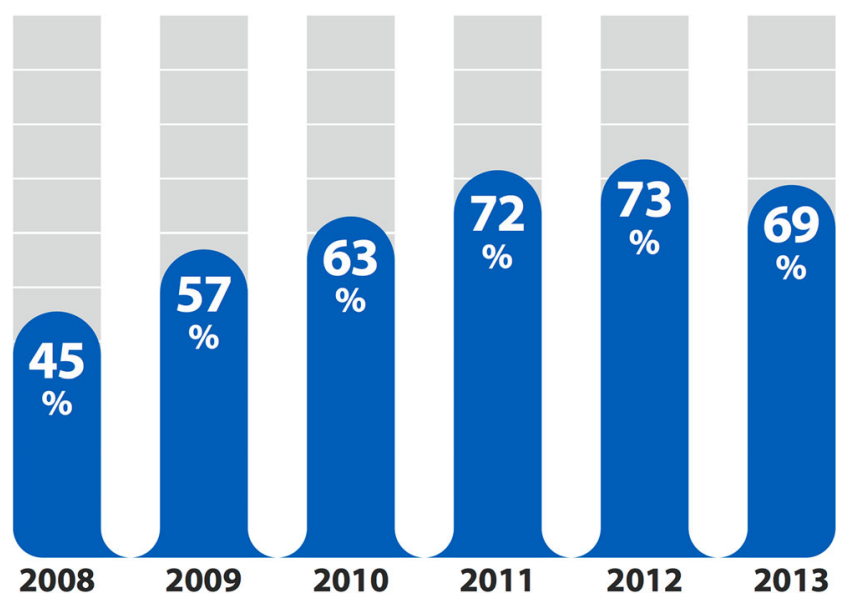

Fig. 5 Fraction of collaborative publications over the first 6 years of GLBRC. The fraction of collaborative manuscripts increased steadily over the first 4 years and has remained in the $70 \%$ range since then 
the diversity required for a comprehensive biofuel research program. Manuscripts include technoeconomic and life cycle assessments of fuel production, engineering and fundamental aspects of diverse biomass pretreatment processes, genomic and metabolic characterization of biomass-degrading and fuel synthesizing microbes, development of tools for analyzing biomass and tracking progress of fermentations, production and analysis of transgenic plants, and plant-fungal symbioses. There is some concentration on the topic of lignin structure, modification, and use. This reflects a trend of all three centers over the past several years toward identifying ways to mitigate lignin's effects on recalcitrance while monetizing this polymer, which comprises up to a third of typical biomass.

The reports provide fundamental new insights while discussing the practical implications of the work. For example, Lu et al. [100] characterize the structure and synthetic pathway of $p$-hydroxybenzoylation of palm tree lignin and point to the potential of $p$-hydroxybenzoate as a value-added product. Baxter et al. [30] describe transgenic switchgrass with genetically modified lignin content and discuss the critical role of field trials in validating transgenic crop performance. Lupoi et al. [101] and Sykes et al. [102] developed new spectrographic methods to characterize lignin and carbohydrate content of biomass, respectively, thereby permitting rapid screening of samples for potential yield of fuel. Konda et al. [103] model the economics of fuel using microalgae feedstock, while Sinistore et al. [18] model ethanol synthesis from switchgrass. The integrative nature of the BRCs focuses and supports this interdisciplinary work, which generates fundamental knowledge while always keeping an eye toward practical implications.

\section{Conclusion}

The BRCs continue to address key challenges in biomass sustainability, recalcitrance, and advanced cellulosic biofuels for this national mission. As always, they continually monitor, and remain responsive to, worldwide developments in biofuels, genomics, agriculture, chemistry, microbiology, and associated fields. In addition to training scores of new bioenergy scientists, the BRC's outreach efforts communicate the value of sustainable bioenergy to the public. Much of this information and hands-on "kitchen science" activities can be found on our websites. For example, GLBRC has targeted high school through undergraduate programs by training instructors and developing instructional modules. BESC has targeted fourth to sixth graders and has reached over 150 , 000 students, parents, and teachers with hands-on science activities.

The ultimate challenge, to be accomplished in collaboration with the various BRC technology transfer organizations, is to translate the basic science developed over the years into robust technology that can be applied to industry. In some cases, this has already begun, with over 100 different BRC technologies already licensed. But other, longer-term programs, particularly those focused on plant modification and development of new biomass cropping systems, will become available only in the next few years.

Collectively, the three Bioenergy Research Centers are providing multiple proofs-of-concept for further improvements for the next generation of cellulosic biofuels capabilities. This is demonstrated in modified and variant biofeedstocks with good agronomic traits, by improved biomass deconstruction and fuel synthesis and by other underlying technologies that enhance the biofuel enterprise. Collectively, this has increased our fundamental understanding of biomass production and conversion. But, perhaps most importantly, the centers and JGI have become models for interdisciplinary collaboration, demonstrating how long-term relationships among diverse teams can lead to sustained and innovative technology development derived from basic science and engineering research.

Acknowledgments This research was funded by the Bioenergy Science Center (BESC), the Great Lakes Bioenergy Research Center (GLBRC), and the Joint BioEnergy Institute (JBEI), which are US Department of Energy Bioenergy Research Centers supported by the Office of Biological and Environmental Research in the DOE Office of Science. BESC is led by ORNL and is managed by UT-Battelle, LLC, Oak Ridge, TN, USA, for the DOE under contract DE-AC05-00OR22725. GLBRC operates under contract \#DE-FC02-07ER64494 to the University of Wisconsin-Madison, in a primary partnership with Michigan State University. JBEI acknowledges the funding support from US DOE's Office of Science, Office of Biological and Environmental Research, through contract DE-AC02-05CH11231 between Lawrence Berkeley National Laboratory and the US DOE.

Conflict of Interest The authors declare that they have no competing interests.

Authors' Contributions SCS, BHD, and BAS outlined, wrote, and edited the manuscript. TSR, KN, and MFP collated and analyzed the combined publication data.

Open Access This article is distributed under the terms of the Creative Commons Attribution 4.0 International License (http:// creativecommons.org/licenses/by/4.0/), which permits unrestricted use, distribution, and reproduction in any medium, provided you give appropriate credit to the original author(s) and the source, provide a link to the Creative Commons license, and indicate if changes were made.

\section{References}

1. Perlack RD, Wright LL, Turhollow AF, Graham RL, Stokes BH, Erbach DC (2005) Biomass as feedstock for a bioenergy and bioproducts industry: the technical feasibility of a billion-ton annual supply. Oak Ridge National Laboratory, Oak Ridge

2. US Department of Energy (2011) U.S. billion-ton update. In: Perlack RD, Stokes BH (eds) Biomass supply for a bioenergy 
and bioproducts industry. Oak Ridge National Laboratory, Oak Ridge

3. Lynd LR, Laser MS, Bransby D, Dale BE, Davison B, Hamilton R, Himmel M, Keller M, McMillan JD, Sheehan J, Wyman CE (2008) How biotech can transform biofuels. Nat Biotechnol 26(2): 169-172

4. US Department of Energy (2006) Breaking the biological barriers to cellulosic ethanol: a joint research agenda

5. US Department of Energy (2006) Vision for bioenergy and biobased products in the United States

6. US Department of Energy and US Department of Agriculture (2002) Vision for bioenergy and biobased products in the United States. In: G.J. English and T.W. Ewing, (ed)

7. Pacific Northwest National Laboratory and National Renewable Energy Laboratory (2004) Top value added chemicals from biomass: volume I - results of screening for potential candidates from sugars and synthesis gas. In: Werpy T, Petersen G, (ed)

8. Pacific Northwest National Laboratory (2007) Top value added chemicals from biomass: volume II-results of screening for potential candidates from biorefinery lignin. In: J.E. Holladay, et al., (ed)

9. Office of Biological and Environmental Research, US Department of Energy (2007) GTL Bioenergy research centers funding opportunity number: DE-PSO2-06ER64304

10. Kalluri UC, Keller M (2010) Bioenergy research: a new paradigm in multidisciplinary research. J R Soc Interface 7(51):1391-1401

11. Lynd LR, Wyman CE, Gerngross TU (1999) Biocommodity engineering. Biotechnol Prog 15(5):777-793

12. Reindl W, Deng K, Cheng X, Singh A, Simmons BA, Adams PD, Northen T (2012) Nanostructure-initiator mass spectrometry (NIMS) for the analysis of enzyme activities. Curr Protoc Chem Biol p. 123-142.

13. Cheng X, Hiras J, Deng K, Bowen B, Simmons BA, Adams PD, Singer SW, Northen TR (2013) High throughput nanostructureinitiator mass spectrometry screening of microbial growth conditions for maximal beta-glucosidase production. Front Microbiol 4: 365

14. Deng K, Takasuka TE, Heins R, Cheng X, Bergeman LF, Shi J, Aschenbrener R, Deutsch S, Singh S, Sale KL, Simmons BA, Adams PD, Singh AK, Fox BG, Northen TR (2014) Rapid kinetic characterization of glycosyl hydrolases based on oxime derivatization and nanostructure-initiator mass spectrometry (NIMS). ACS Chem Biol 9:1470-1479. doi:10.1021/cb5000289

15. Heins RA, Cheng X, Nath S, Deng K, Bowen BP, Chivian DC, Datta S, Friedland GD,D'Haeseleer P, Wu D, Tran-Gyamfi M, Scullin CS, Singh S, Shi W, Hamilton MG,Bendall ML, Sczyrba A, Thompson J, Feldman T, Guenther JM, Gladden JM, Cheng JF, Adams PD, Rubin EM, Simmons BA, Sale KL, Northen TR, SD (2014) Phylogenomically guided identification of industrially relevant GH1 $\beta$-glucosidases through DNA synthesis and nanostructure-initiator mass spectrometry. ACS Chem Biol 9(9): 2082-2091

16. US Department of Energy, (2015) Basic research opportunities in genomic science to advance the production of biofuels and bioproducts from plant biomass

17. Federal Reserve Bank of Minneapolis. CONSUMER PRICE INDEX, 1913-; Available from: http://www.minneapolisfed.org/. Accessed 20 June 2015

18. Sinistore J, Reinemann D, Izaurralde RC, Cronin K, Meier P, Runge T, Zhang X (2015) Life cycle assessment of switchgrass cellulosic ethanol production in the Wisconsin and Michigan agricultural contexts. BioEnergy Research 8. doi: 10.1007/s12155015-9611-4

19. Ghimire SR, Craven KD (2011) Enhancement of switchgrass (Panicum virgatum L.) biomass production under drought conditions by the ectomycorrhizal fungus Sebacina vermifera. Appl Environ Microbiol 77(19):7063-7067

20. Evans LM, Slavov GT, Rodgers-Melnick E, Martin J, Ranjan P, Muchero W, Brunner AM, Schackwitz W, Gunter L, Chen JG, Tuskan GA, DiFazio SP (2014) Population genomics of Populus trichocarpa identifies signatures of selection and adaptive trait associations. Nat Genet 46(10):1089-1096

21. Wilkerson C, Ralph J, Withers S (2013) Feruloyl-CoA: monolignol transferase. US 2013-0203973 A1

22. Wilkerson C, Ralph J, Withers S (2013) Feruloyl-CoA: monolignol transferase. US 2013-0219547 A12013

23. Wilkerson CG, Mansfield SD, Lu F, Withers S, Park JY, Karlen SD, Gonzales-Vigil E,Padmakshan D, Unda F, Rencoret J, Ralph J (2014) Monolignol ferulate transferase introduces chemically labile linkages into the lignin backbone. Science 344(6179):90-93

24. Studer MH, DeMartini JD, Brethauer S, McKenzie HL, Wyman CE (2010) Engineering of a high-throughput screening system to identify cellulosic biomass, pretreatments, and enzyme formulations that enhance sugar release. Biotechnol Bioeng 105(2):231-238

25. Shen H, Poovaiah CR, Ziebell A, Tschaplinski TJ, Pattathil S, Gjersing E, Engle NL,Katahira R, Pu Y, Sykes R, Chen F, Ragauskas AJ, Mielenz JR, Hahn MG, Davis M, Stewart CN, Jr, Dixon RA (2013) Enhanced characteristics of genetically modified switchgrass (Panicum virgatum L.) for high biofuel production. Biotechnol Biofuels 6(1):71

26. Fu C, Mielenz JR, Xiao X, Ge Y, Hamilton CY, Rodriguez M, Jr., Chen F, Foston M,Ragauskas A, Bouton J, Dixon RA, Wang ZY (2011) Genetic manipulation of lignin reduces recalcitrance and improves ethanol production from switchgrass. Proc Natl Acad Sci U S A 108(9):3803-3808

27. Hao Z, Avci U, Tan L, Zhu X, Glushka J, Pattathil S, Eberhard S, Sholes T, Rothstein GE, Lukowitz W, Orlando R, Hahn MG, Mohnen D (2014) Loss of Arabidopsis GAUT12/IRX8 causes anther indehiscence and leads to reduced $\mathrm{G}$ lignin associated with altered matrix polysaccharide deposition. Front Plant Sci 5:357

28. Biswal AK, Hao Z, Pattathil S, Yang X, Winkeler K, Collins C, Mohanty SS, Richardson EA, Gelineo-Albersheim I, Hunt K, Ryno D, Sykes RW, Turner GB, Ziebell A, Gjersing E, Lukowitz W, Davis MF, Decker SR, Hahn MG, Mohnen D (2015) Downregulation of GAUT12 in Populus deltoides by RNA silencing results in reduced recalcitrance, increased growth and reduced xylan and pectin in a woody biofuel feedstock. Biotechnol Biofuels 8:41

29. Chung D, Pattathil S, Biswal AK, Hahn MG, Mohnen D, Westpheling J (2014) Deletion of a gene cluster encoding pectin degrading enzymes in Caldicellulosiruptor bescii reveals an important role for pectin in plant biomass recalcitrance. Biotechnol Biofuels 7(1):147

30. Baxter H, Poovaiah C, Yee K, Mazarei M, Rodriguez M, Jr, Thompson O, Shen H, Turner G, Decker S, Sykes R, Chen F, Davis M, Mielenz J, Davison B, Dixon R, Stewart CN, Jr (2015) Field evaluation of transgenic switchgrass plants overexpressing PvMYB4 for reduced biomass recalcitrance. Bio Energy Res. doi:10.1007/s12155-014-9570-1

31. Kalluri UC, Yin H, Yang X, Davison BH (2014) Systems and synthetic biology approaches to alter plant cell walls and reduce biomass recalcitrance. Plant Biotechnol J 12(9):1207-1216

32. Muchero W, Guo J, DiFazio SP, Chen JG, Ranjan P, Slavov GT, Gunter LE, Jawdy S, Bryan AC, Sykes R, Ziebell A, Klapste J, Porth I, Skyba O, Unda F, El-Kassaby YA, Douglas CJ, Mansfield SD, Martin J, Schackwitz W, Evans LM, Czarnecki O, Tuskan GA (2015) High-resolution genetic mapping of allelic variants associated with cell wall chemistry in Populus. BMC Genomics 16:24

33. Bennetzen JL, Schmutz J, Wang H, Percifield R, Hawkins J, Pontaroli AC, Estep M, Feng L, Vaughn JN, Grimwood J, 
Jenkins J, Barry K, Lindquist E, Hellsten U, Deshpande S, Wang X, Wu X, Mitros T, Triplett J, Yang X, Ye CY, Mauro-Herrera M, Wang L, Li P, Sharma M, Sharma R, Ronald PC, Panaud O, Kellogg EA, Brutnell TP, Doust AN, Tuskan GA, Rokhsar D, Devos KM (2012) Reference genome sequence of the model plant Setaria. Nat Biotechnol 30(6):555-561

34. Zhang JY, Lee YC, Torres-Jerez I, Wang M, Yin Y, Chou WC, He J, Shen H, Srivastava AC, Pennacchio C, Lindquist E, Grimwood J, Schmutz J, Xu Y, Sharma M, Sharma R, Bartley LE, Ronald PC, Saha MC, Dixon RA, Tang Y, Udvardi MK (2013) Development of an integrated transcript sequence database and a gene expression atlas for gene discovery and analysis in switchgrass (Panicum virgatum L.). Plant J 74(1):160-173

35. Manabe Y, Nafisi M, Verhertbruggen Y, Orfila C, Gille S, Rautengarten C, Cherk C, Marcus SE, Somerville S, Pauly M, Knox JP, Sakuragi Y, Scheller HV (2011) Loss-of-function mutation of REDUCED WALL ACETYLATION2 in Arabidopsis leads to reduced cell wall acetylation and increased resistance to Botrytis cinerea. Plant Physiol 155(3):1068-1078

36. Scheller HV (2011) Method of reducing acetylation in plants to improve biofuel production US13/201,851

37. Bart R, Chern MS, Ronald PC, Vega-Sanchez ME (2011) Inhibition of snl6 expression for biofuel production. PCT/ US2011/040941 (WIPO)

38. Jensen JK, Sorensen SO, Harholt J, Geshi N, Sakuragi Y, Moller I, Zandleven J, Bernal AJ, Jensen NB, Sorensen C, Pauly M, Beldman G, Willats WG, Scheller HV (2008) Identification of a xylogalacturonan xylosyltransferase involved in pectin biosynthesis in Arabidopsis. Plant Cell 20(5):1289-1302

39. Oikawa A, Joshi HJ, Rennie EA, Ebert B, Manisseri C, Heazlewood JL, Scheller HV (2010) An integrative approach to the identification of Arabidopsis and rice genes involved in xylan and secondary wall development. PLoS One 5(11):e15481

40. Verhertbruggen Y, Yin L, Oikawa A, Scheller HV (2011) Mannan synthase activity in the CSLD family. Plant Signal Behav 6(10): $1620-1623$

41. Yin L, Verhertbruggen Y, Oikawa A, Manisseri C, Knierim B, Prak L, Jensen JK, Knox JP, Auer M, Willats WG, Scheller HV (2011) The cooperative activities of CSLD2, CSLD3, and CSLD5 are required for normal Arabidopsis development. Mol Plant 4: 1024-1037

42. Lao J, Oikawa A, Bromley JR, McInerney P, Suttangkakul A, Smith-Moritz AM, Plahar H, Chiu T-Y, González FernándezNiño SM, Ebert B, Yang F, Christiansen KM, Hansen SF, Stonebloom S, Adams PD, Ronald PC, Hillson NJ, Hadi MZ, Vega-Sánchez ME, Loqué D, Scheller HV, Heazlewood JL (2014) The plant glycosyltransferase clone collection for functional genomics. Plant J 79(3):517-529

43. Ito J, Batth TS, Petzold CJ, Redding-Johanson AM, Mukhopadhyay A, Verboom R, Meyer EH, Millar AH, Heazlewood JL (2011) Analysis of the Arabidopsis cytosolic proteome highlights subcellular partitioning of central plant metabolism. J Proteome Res 10(4):1571-1582

44. Rautengarten C, Ebert B, Herter T, Petzold CJ, Ishii T, Mukhopadhyay A, Usadel B, Scheller HV (2011) The interconversion of UDP-Arabinopyranose and UDP-Arabinofuranose is indispensable for plant development in Arabidopsis. Plant Cell 23(4):1373-1390

45. Loque D, Scheller HV, (2011) Spatially modified gene expression in plants. US014939-009200

46. Loque D, Eudes A, (2011) Lignification reduction in plants, $U$ 014939-009000

47. Eudes A, George A, Mukerjee P, Kim JS, Pollet B, Benke PI, Yang F, Mitra P, Sun L, Cetinkol OP, Chabout S, Mouille G, SoubigouTaconnat L, Balzergue S, Singh S, Holmes BM, Mukhopadhyay A, Keasling JD, Simmons BA, Lapierre C, Ralph J, Loque D
(2012) Biosynthesis and incorporation of side-chain-truncated lignin monomers to reduce lignin polymerization and enhance saccharification. Plant Biotechnol J 10(5):609-620

48. Bartley LE, Peck ML, Kim SR, Ebert B, Maniseri C, Chiniquy D, Sykes R, Gao L, Rautengarten C, Vega-Sanchez ME, Benke PI, Canlas PE, Cao P, Brewer S, Lin F, Smith WL, Zhang X, Keasling JD, Jentoft RE, Foster SB, Zhou J, Ziebell A, An G, Scheller HV, Ronald PC (2013) Overexpression of a BAHD acyltransferase, OsAt10, alters rice cell wall hydroxycinnamic acid content and saccharification. Plant Physiol 161(4):1615-1633

49. Fox BG, Takasuka T, Bianchetti CM, (2014) Multifunctional cellulase and hemicellulase US20140079683 A1

50. Li C, Knierim B, Manisseri C, Arora R, Scheller HV, Auer M, Vogel KP, Simmons BA, Singh S (2010) Comparison of dilute acid and ionic liquid pretreatment of switchgrass: biomass recalcitrance, delignification and enzymatic saccharification. Bioresour Technol 101(13):4900-4906

51. Li C, Cheng G, Balan V, Kent MS, Ong M, Chundawat SP, Sousa LD, Melnichenko YB, Dale BE, Simmons BA, Singh S (2011) Influence of physico-chemical changes on enzymatic digestibility of ionic liquid and AFEX pretreated corn stover. Bioresour Technol 102(13):6928-6936

52. Dibble DC, Li C, Sun L, George A, Cheng A, Cetinkol OP, Benke P, Holmes B, Singh S, Simmons BA (2011) A facile method for the recovery of ionic liquid and lignin from biomass pretreatment. Green Chem 13:3255-3264

53. Gladden JM, Allgaier M, Miller CS, Hazen TC, Vandergheynst JS, Hugenholtz P, Simmons BA, Singer SW (2011) Glycoside hydrolase activities of thermophilic bacterial consortia adapted to switchgrass. Appl Environ Microbiol 77:5804-5812

54. Reindl W, Deng K, Gladden JM, Cheng G, Wong A, Singer SW, Singh S, Lee JC, Yao CH, Hazen TC, Singh AK, Simmons BA, Adams PD, Northen TR (2011) Colloid-based multiplexed screening for plant biomass-degrading glycoside hydrolase activities in microbial communities. Energy Environ Sci 4:2884-2893

55. Klein-Marcuschamer D, Simmons BA, Blanch HW (2011) Techno-economic analysis of a lignocellulosic ethanol biorefinery with ionic liquid pre-treatment. Biofuels Bioprod Biorefin 5:562569

56. Shi J, Gladden JM, Sathitsuksanoh N, Kambam P, Sandoval L, Mitra D, Zhang S, George A, Singer SW, Simmons BA, Singh S (2013) One-pot ionic liquid pretreatment and saccharification of switchgrass. Green Chem 15(9):2579-2589

57. Konda M, Shi J, Singh S, W BH, Simmons BA, KleinMarcuschamer D (2014) Understanding cost drivers and economic potential of two variants of ionic liquid pretreatment for cellulosic biofuel production. Biotechnol Biofuels 7:86

58. Socha AM, Parthasarathi R, Shi J, Pattathil S, Whyte D, Bergeron M, George A, Tran K, Stavila V, Venkatachalam S, Hahn MG, Simmons BA, Singh S (2014) Efficient biomass pretreatment using ionic liquids derived from lignin and hemicellulose. Proc Natl Acad Sci U S A 111:e3587-e3595

59. Gladden JM, Park JI, Bergmann J, Reyes-Ortiz V, D'Haeseleer P, Quirino BF, Sale KL, Simmons BA, Singer SW (2014) Discovery and characterization of ionic liquid-tolerant thermophilic cellulases from a switchgrass-adapted microbial community. Biotechnol Biofuels 7(1):15

60. Reddy AP, Liles MR, Simmons CW, D'haeseleer P, Khudyakov J, Burd H, Hadi M, Simmons BA, Singer SW, Thelen MP, VanderGheynst JS (2013) Discovery of microorganisms and enzymes involved in high-solids decomposition of rice straw using metagenomic analyses. PLoS One 8(10):e77985

61. Olson DG, McBride JE, Shaw AJ, Lynd LR (2012) Recent progress in consolidated bioprocessing. Curr Opin Biotechnol 23(3): 396-405 
62. Blumer-Schuette SE, Brown SD, Sander KB, Bayer EA, Kataeva I, Zurawski JV, Conway JM, Adams MW, Kelly RM (2014) Thermophilic lignocellulose deconstruction. FEMS Microbiol Rev 38(3):393-448

63. Lynd LR, Weimer PJ, van Zyl WH, Pretorius IS (2002) Microbial cellulose utilization: fundamentals and biotechnology. Microbiol Mol Biol Rev 66(3):506-577

64. Chung D, Farkas J, Huddleston JR, Olivar E, Westpheling J (2012) Methylation by a unique alpha-class N4-cytosine methyltransferase is required for DNA transformation of Caldicellulosiruptor bescii DSM6725. PLoS One 7(8):e43844

65. Yang S, Giannone R, Dice L, Yang Z, Engle N, Tschaplinski T, Hettich R, Brown S (2012) Clostridium thermocellum ATCC27405 transcriptomic, metabolomic and proteomic profiles after ethanol stress. BMC Genomics 13(1):336

66. Shao X, Raman B, Zhu M, Mielenz J, Brown S, Guss A, Lynd L (2011) Mutant selection and phenotypic and genetic characterization of ethanol-tolerant strains of Clostridium thermocellum. Appl Microbiol Biotechnol 92(3):641-652

67. Brown SD, Guss AM, Karpinets TV, Parks JM, Smolin N, Yang S, Land ML, Klingeman DM, Bhandiwad A, Rodriguez M, Raman B, Shao X, Mielenz JR, Smith JC, Keller M, Lynd LR (2011) Mutant alcohol dehydrogenase leads to improved ethanol tolerance in Clostridium thermocellum. Proc Natl Acad Sci U S A 108(33):13752-13757

68. Kataeva I, Foston MB, Yang S-J, Pattathil S, Biswal AK, Poole Ii FL, Basen M, Rhaesa AM, Thomas TP, Azadi P, Olman V, Saffold TD, Mohler KE, Lewis DL, Doeppke C, Zeng Y, Tschaplinski TJ, York WS, Davis M, Mohnen D, Xu Y, Ragauskas AJ, Ding S-Y, Kelly RM, Hahn MG, Adams MWW (2013) Carbohydrate and lignin are simultaneously solubilized from unpretreated switchgrass by microbial action at high temperature. Energy Environ Sci 6(7):2186-2195

69. Brunecky R, Alahuhta M, Xu Q, Donohoe BS, Crowley MF, Kataeva IA, Yang SJ, Resch MG, Adams MW, Lunin VV, Himmel ME, Bomble YJ (2013) Revealing nature's cellulase diversity: the digestion mechanism of Caldicellulosiruptor bescii CelA. Science 342(6165):1513-1516

70. Resch MG, Donohoe BS, Baker JO, Decker SR, Bayer EA, Beckham GT, Himmel ME (2013) Fungal cellulases and complexed cellulosomal enzymes exhibit synergistic mechanisms in cellulose deconstruction. Energy Environ Sci 6(6):1858-1867

71. Cheng G, Datta S, Liu Z, Wang C, Murton JK, Brown PA, Jablin MS, Dubey M, Majewski J, Halbert CE, Browning JF, Esker AR, Watson BJ, Zhang H, Hutcheson SW, Huber DL, Sale KL, Simmons BA, Kent MS (2012) Interactions of endoglucanases with amorphous cellulose films resolved by neutron reflectometry and quartz crystal microbalance with dissipation monitoring. Langmuir 28(22):8348-8358

72. Gao X, Kumar R, Singh S, Simmons BA, Balan V, Dale BE, Wyman CE (2014) Comparison of enzymatic reactivity of corn stover solids prepared by dilute acid, AFEX, and ionic liquid pretreatments. Biotechnol Biofuels 7(71):1754-6834

73. Uppugundla N, da Costa Sousa L, Chundawat SP, Yu X, Simmons B, Singh S, Gao X, Kumar R, Wyman CE, Dale BE, Balan V (2014) A comparative study of ethanol production using dilute acid, ionic liquid and AFEX pretreated corn stover. Biotechnol Biofuels 7(1):72

74. Higashide W, Li Y, Yang Y, Liao JC (2011) Metabolic engineering of Clostridium cellulolyticum for production of isobutanol from cellulose. Appl Environ Microbiol 77(8):2727-2733

75. Yee KL, Rodriguez M, Jr, Thompson OA, Fu C, Wang ZY, Davison BH, Mielenz JR (2014) Consolidated bioprocessing of transgenic switchgrass by an engineered and evolved Clostridium thermocellum strain. Biotechnol Biofuels 7:75
76. Runguphan W, Keasling JD (2014) Metabolic engineering of Saccharomyces cerevisiae for production of fatty acid-derived biofuels and chemicals. Metab Eng 21:103-113

77. Goh EB, Baidoo EE, Keasling JD, Beller HR (2012) Engineering of bacterial methyl ketone synthesis for biofuels. Appl Environ Microbiol 78(1):70-80

78. Peralta-Yahya PP, Ouellet M, Chan R, Mukhopadhyay A, Keasling JD, Lee TS (2011) Identification and microbial production of a terpene-based advanced biofuel. Nat Commun 2:483

79. Alonso-Gutierrez J, Chan R, Batth TS, Adams PD, Keasling JD, Petzold CJ, Lee TS (2013) Metabolic engineering of Escherichia coli for limonene and perillyl alcohol production. Metab Eng 19C: 33-41

80. Galdzicki M, Clancy KP, Oberortner E, Pocock M, Quinn JY, Rodriguez CA, Roehner N, Wilson ML, Adam L, Anderson JC, Bartley BA, Beal J, Chandran D, Chen J, Densmore D, Endy D, Grunberg R, Hallinan J, Hillson NJ, Johnson JD, Kuchinsky A, Lux M, Misirli G, Peccoud J, Plahar HA, Sirin E, Stan G-B, Villalobos A, Wipat A, Gennari JH, Myers CJ, Sauro HM (2014) The Synthetic Biology Open Language (SBOL) provides a community standard for communicating designs in synthetic biology. Nat Biotechnol 32(6):545-550

81. Hillson NJ (2014) j5 DNA assembly design automation, in DNA cloning and assembly methods. In: Valla S Rahmi L, (ed). Humana Press. p 245-269

82. Linshiz G, Stawski N, Goyal G, Bi C, Poust S, Sharma M, Mutalik V, Keasling JD, Hillson NJ (2014) PR-PR: cross-platform laboratory automation system. ACS Syn Biol, p. 140114162902002.

83. Skerker JM, Leon D, Price MN, Mar JS, Tarjan DR, Wetmore KM, Deutschbauer AM, Baumohl JK, Bauer S, Ibanez AB, Mitchell VD, Wu CH, Hu P, Hazen T, Arkin AP (2013) Dissecting a complex chemical stress: chemogenomic profiling of plant hydrolysates. Mol Syst Biol 9:674

84. Schwalbach MS, Keating DH, Tremaine M, Marner WD, Zhang Y, Bothfeld W, Higbee A, Grass JA, Cotten C, Reed JL, da Costa Sousa L, Jin M, Balan V, Ellinger J, Dale B, Kiley PJ, Landick R (2012) Complex physiology and compound stress responses during fermentation of alkali-pretreated corn stover hydrolysate by an Escherichia coli ethanologen. Appl Environ Microbiol 78(9): 3442-3457

85. Piotrowski JS, Zhang Y, Bates DM, Keating DH, Sato TK, Ong IM, Landick R (2014) Death by a thousand cuts: the challenges and diverse landscape of lignocellulosic hydrolysate inhibitors. Front Microbiol 5:90

86. Haft RJ, Keating DH, Schwaegler T, Schwalbach MS, Vinokur J, Tremaine M, Peters JM, Kotlajich MV, Pohlmann EL, Ong IM, Grass JA, Kiley PJ, Landick R (2014) Correcting direct effects of ethanol on translation and transcription machinery confers ethanol tolerance in bacteria. Proc Natl Acad Sci U S A 111(25):e2576e 2585

87. Sen SM, Binder JB, Raines RT, Maravelias CT (2012) Conversion of biomass to sugars via ionic liquid hydrolysis: process synthesis and economic evaluation. Biofuel Bioprod Biorefin 6(4):444-452

88. Caes B, Van Oosbree T, Lu F, Ralph J, Maravelias CT, Raines RT (2013) Simulated moving bed chromatography: separation and recovery of sugars and ionic liquid from biomass hydrolysates. ChemSusChem 6:2083-2089

89. Alonso DM, Gallo JMR, Mellmer MA, Wettstein SG, Dumesic JA (2013) Direct conversion of cellulose to levulinic acid and gamma-valerolactone using solid acid catalysts. Catal Sci Technol 3:927-931

90. Alonso DM, Wettstein SG, Bond JQ, Root TW, Dumesic JA (2011) Production of biofuels from cellulose and corn stover using alkylphenol solvents. ChemSusChem 4(8):1078-1081 
91. Alonso DM, Wettstein SG, Mellmer MA, Gurbuz EI, Dumesic JA (2012) Integrated conversion of hemicellulose and cellulose from lignocellulosic biomass. Energy Environ Sci 6:76-80

92. Han J, Luterbacher JS, Alonso DM, Dumesic JA, Maravelias CT (2015) A lignocellulosic ethanol strategy via nonenzymatic sugar production: process synthesis and analysis. Bioresour Technol 182:258-266

93. Luterbacher JS, Martin Alonso D, Dumesic JA (2014) Targeted chemical upgrading of lignocellulosic biomass to platform molecules. Green Chem 16(12):4816-4838

94. Han J, Sen SM, Alonso DM, Dumesic JA, Maravelias CT (2014) A strategy for the simultaneous catalytic conversion of hemicellulose and cellulose from lignocellulosic biomass to liquid transportation fuels. Green Chem 16:653-661

95. Brown ME, Chang MC (2014) Exploring bacterial lignin degradation. Curr Opin Chem Biol 19:1-7

96. Bugg TD, Ahmad M, Hardiman EM, Rahmanpour R (2011) Pathways for degradation of lignin in bacteria and fungi. Nat Prod Rep 28(12):1883-1896

97. Deangelis KM, Sharma D, Varney R, Simmons B, Isern NG, Markilllie LM, Nicora C, Norbeck AD, Taylor RC, Aldrich JT, Robinson EW (2013) Evidence supporting dissimilatory and assimilatory lignin degradation in Enterobacter lignolyticus SCF1. Front Microbiol 4:280
98. Rahimi A, Azarpira A, Kim H, Ralph J, Stahl SS (2013) Chemoselective metal-free aerobic alcohol oxidation in lignin. J Am Chem Soc 135(17):6415-6418

99. Rahimi A, Ulbrich A, Coon JJ, Stahl SS (2014) Formic-acidinduced depolymerization of oxidized lignin to aromatics. Nature 515(7526):249-252

100. Lu F, Karlen, S, Regner M, Kim H, Ralph SA, Sun R-C, Kuroda K, Augustin MA, Mawson R, Sabarez H, Singh T, Jimenez-Monteon G, Zakaria S, Hill S, Harris PJ, Boerjan W, Wilkerson C, Mansfield SD, Ralph J (2015) Naturally p-hydroxybenzoylated lignin in palms. Bioenergy Res 8 . doi: 10.1007/s12155-015-9583-4

101. Sykes RW, Gjersing EL, Doeppke CL, Davis MF (2015) Highthroughput method for determining the sugar content in biomass with pyrolysis molecular beam mass spectrometry. Bioenergy Res 8. doi: 10.1007/s12155-015-9610-5

102. Konda MNVSN, Singh S, Simmons BA, Klein-Marcuschamer D (2015) High-throughput method for determining the sugar content in biomass with pyrolysis molecular beam mass spectrometry. Bioenergy Res

103. Konda, M.N.V.S.N, et al (2015) An investigation on the feasibility of microalgae as potential feedstock for biorefineries. Bioenergy Res 8. doi: 10.1007/s12155-015-9594-1 